Vol. 1, No. 1, Juli 2017, 76-85

Available Online at https://ejournal.warmadewa.ac.id/index.php/kulturistik

DOI: dx.doi.org/10.22225/kulturistik.1.1.219

\title{
PRAKTIK BENTUK BANTEN PRAYASCITA DI KOTA DENPASAR
}

\author{
Ni Ketut Sukiani \\ Universitas Warmadewa \\ ketutsukiani@gmail.com
}

\begin{abstract}
ABSTRAK
Dalam pelaksanaan upacara agama Hindu di Bali, sangat banyak jenis dan bentuk banten yang dipergunakan. Hal ini menyebabkan masyarakat kurang memahami bentuk dari banten yang ada secara benar. Khususnya pada banten Prayascita, dimana banten ini memiliki beragam bentuk. Penelitian ini bertujuan untuk memperdalam pengetahuan tentang bentuk-bentuk dari banten Prayascita yang digunakan dalam pelaksanaan upacara agama oleh masyarakat Hindu. Dalam penelitian ini, sumber data didapatkan dengan cara melakukan tinjauan pustaka dan wawancara kepada narasumber yang merupakan pakar agama sekaligus pakar dalam pembuatan banten. Penelitian ini menggunakan metode penelitian kualitatif melalui pendekatan kualitatif yang lebih menitik beratkan pada keutuhan sebuah fenomena budaya. Banten Prayascita merupakan salah satu dari berbagai jenis banten yang memiliki fungsi yang sangat penting dan hampir selalu digunakan dalam setiap pelaksanaan upacara agama Hindu. Terdapat berbagai ragam bentuk banten Prayascita yang dipergunakan dalam pelaksaan upacara agama Hindu. Bentuk banten Prayascita yang paling umum digunakan yaitu banten Prayascita biasa, banten Prayascita sakti, dan banten Prayascita luwih.
\end{abstract}

Kata kunci: Banten Prayascita, Prayascita biasa, Prayascita sakti, Prayascita luwih.

\begin{abstract}
[Title: The form of Banten Prayascita at Denpasar City] In the implementation of Hindu traditional reigious ceremonies in Bali, there are many types and forms of banten that are used. This causes the people's lack understanding of the correct form of the banten. Especially on Prayascita banten, in which this banten has various forms. This study aims to deepen the knowledge of the forms of Prayascita banten used in the conduct of religious ceremonies by Hindu people, thus will let people know the right form of banten Prayascita. In this research, the data source obtained by doing literature review and interviews to interviewees who are experts in religion as well as experts in making the banten itself. This research uses qualitative research methods through a qualitative approach that spend more focuses on the integrity of a cultural phenomenon. Banten Prayascita is one of many kinds of banten which has very important function and always used in every implementation of Hindu traditional religious ceremony. There are various forms of Prayascita banten used in Hindu ceremonies. The most common forms of Prayascita banten are banten Prayascita biasa, banten Prayascita sakti, and banten Prayascita luwih.
\end{abstract}

Keywords: Banten Prayascita, Prayascita biasa, Prayascita sakti, Prayascita luwih.

\section{PENDAHULUAN}

Pedoman dalam pelaksanaan ajaran Agama Hindu terdiri atas Tatwa, Susila dan Upakara yang terjalin menjadi satu kesatuan yang tidak dapat dipisahkan, harus berjalan seimbang dan saling terkait untuk mencapai kesempurnaan. Secara 
umum pemahaman Umat Hindu di Bali terhadap Tatwa, Susila dan Upakara masih kurang dan bervariasi. Perbedaan pengalaman maupun pengetahuan tentang ajaran agama menimbulkan persepsi berbeda dan sering keliru. Dalam praktik beragama lebih didominasi oleh pemahaman etika dan upakara sehingga muncul sikap fanatik, pengeluaran yang tidak terarah dan cenderung boros. Perubahan zaman semakin maju, pengetahuan tentang agama semakin kritis sehingga timbul keinginan untuk mengetahui dengan jelas dan benar tentang upacara terutama fungsi dan perlengkapannya. Salah satu diantaranya adalah tentang banten.

Dari perspektif sejarah banten diduga berasal dari India. Banten telah menjadi bagian dari budaya masyarakat seiring dengan perjalanan masuknya Agama Hindu ke Bali. Walaupun demikian diyakini bahwa, ada beberapa banten merupakan hasil ciptaan masyarakat Bali yang disesuaikan dengan kondisi alam pulau Bali. Tokoh- tokoh agama mengatakan banten dari India masuk melalui Pulau Jawa pada zaman kerajaan Medang Kemulan. Raja meminta Empu Gagak Aking dengan paham Siwa dan Empu Bubuksah dengan paham Budha untuk menuliskan buku tentang banten yang lebih menitikberatkan pada banten Dewa Yadnya dengan nama-nama tertentu. Selanjutnya, Raja Pujungan di Bali mengenal istilah banten atau aci seperti banten Ngenteg Jagat, banteng Ngusaba Desa, banten Ngusaba Nini. Pada saat terjadi malapetaka atau bencana, raja bersama pendeta mendapatkan pawisik mengisyaratkan untuk dilaksanakan upacara mengatasi malapetaka (Rana, 1972).

Seiring perjalanan waktu, umat semakin kritis ingin mengetahui fungsi dan makna banten berdasarkan sastra, sesuai dengan yang dimuat dalam kitab-kitab suci, dan tidak terjebak dengan jawaban mule keto. Fenomena menarik dalam beberapa tahun terakhir, muncul polemik tentang banten. Keterbatasan waktu untuk menyiapkan banten dalam setiap upacara mengingat besarnya tuntutan bekerja, kesibukan umat meningkat sehingga umat cenderung untuk membeli banten. Bagi masyarakat yang sibuk bekerja membeli banten adalah satu cara untuk tetap melaksanakan kewajiban dan keyakinan agama (Rianingsih, 2004).

Upacara keagamaan dalam ajaran Agama Hindu digolongkan dalam Panca Yadnya dan semua proses kegiatan upacara ini menggunakan sarana banten. Banten merupakan simbol yang berkedudukan khas, melambangkan sifat Tuhan sebagai wujud cinta kasih dan pelepasan ikatan yang dituangkan dalam kreatifitas manusia dalam perjalanan hidupnya mencari hakikat kebenaran. Keyakinan umat Hindu di Bali berdasarkan kepercayaan yang diwariskan leluhur bahwa banten lahir dari penyikapan pengalaman bathin yang mendalam melalui laku tapa, brata, yoga dan semadhi. Dalam setiap kelompok yadnya banten mengandung nilai simbolik, spritual dan estetis. Salah satu dari jenis banten adalah banten Prayascita.

Banten Prayascita merupakan salah satu jenis banten yang memiliki posisi sangat penting dan selalu digunakan dalam pelaksanaan upacara. Prayascita antara lain digunakan sebagai penyucian, baik melengkapi banten biyakala, banten pemujaan ditempatkan di depan pendeta saat melakukan pemujaan, menyucikan bangunan yang baru direnovasi, maupun jika ada keluarga baru meninggal (cuntaka) serta kekeruhan pikiran dan perasaan (Putra, 2000). Dalam upacara manusia yadnya banten prayascita digunakan dalam upacara ngotonin anak yang belum tanggal giginya, sedangkan anak yang sudah tanggal giginya diganti dengan banten byakala (Arwati, 1993). Keterangan mengenai penggunaan 
prayascita sebagai banten pembersihan dan penyucian terhadap cuntaka dijelaskan dalam lontar cuntaka. Prayascita menurut kamus istilah Agama Hindu berasal dari kata "tebasan" = tebus, beli. Tebasan adalah sarana atau banten untuk menebus dosa seseorang atau upacara penyucian. Menurut Sri Reshi Anandakusuma dalam kamus bahasa Bali praya artinya hasrat atau keinginan. Prayascita adalah pembersihan untuk kotoran yang ringan atau sedikit. Tetebasan prayascita bermakna sarana penyucian Tri Bhuwana, menyucikan alam swah loka dalam wujud Tri Mandala sebagai penyucian Utama Mandala, wujud Tri Premana penyucian idep dan Tri Kaya Parisudha menyucikan pikiran. Dalam pikiran suci akan menimbulkan aktifitas yang suci pula (Wijayananda, 2004). Banten prayascita termasuk banten yang memiliki mutu kedewataan (Daiwi Sampad) berfungsi sebagai pembersihan dan mengandung nilai religius sebagai kekuatan siwa guru. Air sucinya dipercikan kearah ubun-ubun (siwa dwara) serta ngayab (natab) kearah kepala karena kekuatan Siwa dalam buana alit bersemayam dalam ubun-ubun (Sudarsana, 2002).

Penelitian ini menggunakan teori Fungsional Struktural menekankan pada keteraturan dan mengabaikan konflik, perubahan-perubahan dalam masyarakat. Konsep utamanya adalah fungsi, disfungsi, fungsi laten, fungsi manifest dan keseimbangan. Selain itu juga menerapkan Teori Simbol untuk menggambarkan sesuatu khususnya sesuatu inmaterial, abstrak, ide, kualitas suatu objek, proses dan lainnya (Coulson dalam Titib I Made, 2003). Simbol dapat berfungsi (Titib, 2003) sebagai cara meningkatkan dan memantapkan sradha, menumbuhkembangkan, terpeliharanya seni buadaya dan memupuk kebersamaan dikalangan masyarakat Hindu melalui sarana pemujaan.

Banten prayascita hampir selalu digunakan di masyarakat dalam upacara agama Hindu, baik pada upacara tingkatan Nista, Madya, maupun Utama. Dilihat dari bentuk, banten prayascita pada setiap daerah hampir serupa, perbedaan hanya terlihat dari kreativitas dan seni masyarakat setempat. Namun hal tersebut tetap memiliki fungsi yang sama yaitu sebagai sarana penyucian.

Penelitian tentang bebantenan jumlahnya sangat terbatas, beberapa penelitian yang terkait bebantenan diantaranya (Rana, 1972) berjudul "Tjara Pembuatan Lis di Pajangan", (Anom, 1987) berjudul "Arti dan Fungsi Kayu Dapdap dalam Kehidupan Masyarakat Hindu di Bali", (Arwati, 1993) berjudul "Jenis-jenis banten sesayut", (Putra, 2000) berjudul " Upacara Dewa Yadnya", (Rasni, 1983) berjudul "Fungsi Upacara Sesayut Prayascita Gumi dalam Upacara Budha Yadnya di Kabupaten Badung, (Rianingsih, 2004) berjudul Faktor-Faktor yang Berpengaruh terhadap Pengembangan Usaha Canang Sari di Kabupaten Badung, (Suika, 1981) berjudul " Arti dan Fungsi Lis dalam Upacara Piodalan di Pura Jaganatha.

Dari uraian diatas, belum terdapat penelitian yang membahas secara mendalam mengenai banten prayascita. Penelitian bertujuan mengkaji kaidah-kaidah agama dalam banten prayascita agar dipahami sebagai bentuk banten yang mempunyai nilai penting dalam pelaksanaan upacara.

\section{METODE}

Lokasi penelitian ini dilaksanakan di kota Denpasar. Penelitian dengan pendekatan kualitatif yang lebih menitikberatkan keutuhan (entity) sebuah fenomena budaya bukan memandang secara parsial. Peneliti berusaha menggambarkan fenomena sosial secara holistik tanpa perlakuan manipulatif. 
Data yang diperlukan berupa data kualitatif bersumber dari teks dan konteksnya dengan sumber data berupa sumber data dokumenter dan sumber data lapangan. Pengumpulan data dilakukan melalui telaah pustaka, observasi terlibat dan wawancara mendalam. Peneliti melakukan analisis data secara deskriptif dengan menggambarkan data yang sudah dikumpulkan tanpa maksud membuat generalisasi dari hasil penelitian.

\section{PEMBAHASAN}

Dalam pembuatan upakara khususnya di Bali memiliki penggolongan atau pengelompokan sesuai dengan fungsinya (Sudarsana \& Dkk., n.d.), yaitu Kalpa, Sukla Kalpa, Kresna Kalpa, Boda Kalpa, Siwa Kalpa. Kalpa dalam upakara memiliki seni dan budaya berupa tetuasan atau reringgitan sebagai nilai satra yang dirangkum menjadi bahasa tertentu yang memiliki makna dan tujuan sebagai permohonan kehadapan Ida Sang Hyang Widi Wasa. Sukla Kalpa dalam upakara adalah sarana yang bersifat suci seperti banten suci. Kresna Kalpa dalam upakara adalah semua jenis buah-buahan, ubi-ubian, tebu, buah kelapa, buah pinang, kemiri, buah pangi, daun selepan, daun enau dan telor. Boda Kalpa dalam upakara adalah semua sarana yang berbentuk rerasmen dalam tetandingan, semua jenis olah-olahan, bawang, jahe, semua jenis bebakaran, salaran, semua jenis ulam daging. Siwa Kalpa dalam upakara adalah semua bentuk tetuasan yang berbentuk segi empat sebagai simbol Arda Chandra dengan kekuatan Siwa, berbentuk bundar sebagai simbol Windhu sebagai kekuatan Sadha Siwa, berbentuk segi tiga sebagai simbol Nadha kekuatan Parama Siwa. Bentuk jejahitan yang dipergunakan dalam upakara, dapat berbentuk segi tiga (tangkih, celemik, ituk-ituk, celekontong, kojong, pelaus uras sari, kepet-kepetan), bentuk segi empat (taledan dan ceper), Bentuk bulat atau bundar (tamas, kulit tebasan, kulit sesayut, sampyan, uras sari dan wadah uyah), bentuk tertentu (Bajra, Dupa, Gada, Moksala, Nagapasa, Angkus, Cakra, Trisula dan Padma untuk jejahitan lis sekepan atau lis senjata Dewata Nawasanga.

Perlengkapan yang diperlukan dalam pembuatan banten prayascita diantaranya kulit sesayut, kulit peras, nasi, rerasmen, jajan, buah-buahan, sorohan alit, pesucian, penyeneng, sampian nagasari, babuhu, padma lis senjata, kelapa gading muda (kelungah), air bersih, air suci (tirta) yang dimohon dari sulinggih. Jejahitan yang dibuat diusahakan menggunakan janur kelapa gading khususnya padma dan lis senjatanya. Cara mengaturnya sama dengan banten byakala tetapi alasnya dapat digunakan baki berturut-turut disusun kulit sesayut, kulit peras (berbentuk bundar), nasi bentuk bundar diisi sedikir rerasmen, lima iris telur dadar diletakkan sedemikian rupa sehingga menunjukkan arah mata angin sedangkan perlengkapan lainnya diletakkan disekitarnya. Kelapa gading muda dibuka dengan bentuk segitiga disebut kasturi. Prayascita dibuat dari janur yang alasnya berbentuk bundar dengan lebar 30-35 cm (tamas gede) didalamnya tersusun sebagai berikut: dipinggiran tamas dijaritkan bentuk tulung 5 buah diisi nasi, kacang saur, disela-selanya dijaritkan tipat kukur 5 buah, disela-sela tipat kukur diisi tumpeng kecil berisi pekir bunga duren dan masing-masing tumpeng ditancapkan kwangen. Ditengah-tengah tamas dipasangkan nasi soda, diatasnya diisi sampian naga sari, dibagian hulunya jajan uli merah putih, jajan begina merah putih, pisang atau buah-buahan, tebu, diisi porosan, kekaputan tape, penyeneng, berisi padma dan lis senjata bajera dan danda, diisi ceper perangkat tepung tawar, sigsig ambuh (pengeresikan), dan pengelanga (kapas berisi minyak 
Vol. 1, No. 1, Juli 2017, 80

Available Online at https://ejournal.warmadewa.ac.id/index.php/kulturistik

DOI: dx.doi.org/10.22225/kulturistik.1.1.219

wangi), tempat tirta, bungkak kelapa gading atau periuk kecil berisi air bersih, berisi usehan sebagai tempat sambal dan kacang saur. Jika membuat prayascita luwih maka tetandingan hampir sama hanya saja tulungnya berjumlah 10 buah, tipat kukur dan kwangen masing-masing 10 dan ditengah nasi soda ditutup dengan sampaian cili memakai lis dengan reringgitan memakai 5 senjata misalnya bajra, gada, danda, cakra dan trisula (Sudarsana, 2002).

Beberapa bentuk tetandingan banten prayascita berdasarkan beberapa nara sumber, diantaranya :

Tabel 1. Jenis Banten Prayascita ${ }^{1}$

\begin{tabular}{|c|c|c|}
\hline No & $\begin{array}{c}\text { Jenis } \\
\text { Prayacita }\end{array}$ & Tetandingan \\
\hline 1 & $\begin{array}{l}\text { Prayascita } \\
\text { Biasa }\end{array}$ & $\begin{array}{l}\text { Kulit sesayut, } 5 \text { lembar daun tabia bun dijahit pada kulit sayut, isi raka-raka } \\
\text { (pisang, tebu, jajan, dan lain-lain. } 1 \text { buah nasi bundar maklongkong, } 5 \\
\text { ujung/ muncuk dapdap dan muncuk ambengan (alang-alang), } 3 \text { rumput / } \\
\text { padang lepas ( } 3 \text { katih), } 1 \text { soroh (peras, tulung, sayut) yang kecil, } 1 \text { buah } \\
\text { kojong rangkadan, masing-masing isi : kacang, saur, gerang, tulung atau } \\
\text { sejenisnya, } 1 \text { penyeneng, } 1 \text { buah lis senjata, } 1 \text { buah canang pabresihan, } 1 \\
\text { buah sampyan nagasari, tepung tawar (daun dadap dan beras ditumbuk } \\
\text { halus, } 1 \text { buah bungkak kelapa gading dikasturi, tirta dari sulinggih, } 1 \text { buah } \\
\text { payuk prayascita. }\end{array}$ \\
\hline 2 & $\begin{array}{l}\text { Prayascita } \\
\text { Sakti }\end{array}$ & $\begin{array}{l}1 \text { buah kulit sayut, } 8 \text { lembar daun tabia bun, diatas kulit sesayut diisi raka- } \\
\text { raka (pisang, apel, jajan secukupnya, ditengah-tengah diisi nasi berbentuk } \\
\text { bundar, diatas nasi diletakkan } 5 \text { iris telor dadar sesuai pengider (arah mata } \\
\text { angin), } 1 \text { buah kojong rangkap lengkap dengan rerasmenan, } 1 \text { soroh peras, } \\
\text { tulung, sayut, } 1 \text { pebresihan payasan, canang genten/ canang burat wangi, } 1 \\
\text { takir beras kuning, } 1 \text { takir reranggitan isinya suah, meke, petat dan } \\
\text { tampelan, bungkak gading dikasturi, sampyan nagasari, wadah uyah, } \\
\text { penyeneng benang tetebus, lis senjata, bebuu atau lis amu-amuan dan } \\
\text { padma, payuk prayascita, tirta dari sulinggih. Semua jejahitan } \\
\text { menggunakan janur kelapa gading. }\end{array}$ \\
\hline 3 & $\begin{array}{l}\text { Prayascita } \\
\text { Gumi }\end{array}$ & $\begin{array}{l}1 \text { buah dulang sebagai alasnya, diatasnya diisi kulit sesayut, diatas kulit } \\
\text { sesayut diisi tumpeng sebanyak } 9 \text { warna, letak tumpeng sesuai dengan arah } \\
\text { mata angin, diatas tumpeng diisi bunga sesuai warna tumpeng, tumpeng } \\
\text { diisi horthi, ketipat sidha purna, ketipat pandhawa, ketipat sari, tulung urip, } \\
\text { tulung sangkur, } 5 \text { bantal pudak diletakkan sesuai mata angin, } 5 \text { pisang } \\
\text { gading diletakkan sesuai mata angin, } 5 \text { jenis woh-wohan, } 5 \text { penek } \\
\text { diletakkan sesuai mata angin, diatas penek disisipi bungan sulasih dan } \\
\text { muncuk dapdap, benang tetebus, canang, payasan pebresihan, } 1 \text { bungkak } \\
\text { kelapa gading dikasturi, } 9 \text { kwangen diletakkan } 9 \text { penjuru mata angin, } \\
\text { sampian peras, penyeneng, tulung urip dan tulung sangkur, } 400 \text { sesantun } 1 \\
\text { buah, daging itik diguling, lis padma, lis senjata terdiri dari Gada, Bajra, } \\
\text { Cakra, Nagapase dan padma. }\end{array}$ \\
\hline 4 & $\begin{array}{l}\text { Prayascita } \\
\text { Kawi }\end{array}$ & $\begin{array}{l}\text { Medasar antuk dulang diatas dulang diisi kulit sayut, } 1 \text { buah tumpeng besar, } \\
\text { diatasnya ditancapkan } 3 \text { buah kwangen, tetebus } 3 \text { pasang (benang putih, } \\
\text { benang sudhamala, benang tridatu), Tumpeng yang kecil ditancapkan } \\
\text { bunga warna-warni (sarwa sekar), } 2 \text { buah tulung, raka-raka secukupnya } \\
\text { (sanganan sarwa galah), kojong rangkadan lengkap dengan rerasmen } \\
\text { (sudang/gerang, telor, kacang dan saur), penyeneng kecil (tehenan), } 1 \text { buah } \\
\text { peras alit, } 1 \text { buah sampian nagasari, canang payasan. }\end{array}$ \\
\hline
\end{tabular}

\footnotetext{
1 Sumber: Ida Pedanda Gde Oka Pinatih, Ida Pedanda Istri Mas dan Ida Ayu Ratnawati (Tukang Banten) Griya Carik Sidemen Karangasem, Wawancara pada tanggal 14 April 2006 dan 18 Juni 2006
}

KULTURISTIK: Jurnal Bahasa dan Budaya E-ISSN: 2580-4456 P-ISSN: 2580-9334 
Vol. 1, No. 1, Juli 2017, 81

Available Online at https://ejournal.warmadewa.ac.id/index.php/kulturistik DOI: dx.doi.org/10.22225/kulturistik.1.1.219

Tabel 2. Jenis Banten Prayascita ${ }^{2}$

\begin{tabular}{|c|c|c|}
\hline No & $\begin{array}{c}\text { Jenis } \\
\text { Prayacita }\end{array}$ & Tetandingan \\
\hline 1 & $\begin{array}{l}\text { Prayascita } \\
\text { Biasa }\end{array}$ & $\begin{array}{l}\text { 1 buah kapar/ nampan diatasnya diisi kulit sesayut, raka-raka } \\
\text { selengkapnya, nasinya berbentuk bundar maklongkong dengan dialasi } 5 \\
\text { lembar daun tabia bun dijahit bundar dan ditempel pada kulit sayut. } \\
\text { Diatasnya nasi ditancapkan } 3 \text { pucuk dadap dan } 3 \text { pucuk padang lepas, } \\
\text { kojong rangkadan, pebresihan payasan, } 1 \text { soroh peras, tulung sayut, } \\
\text { setangkir beras kuning, setangkir reranggitan, payuk prayascita, tirta, } \\
\text { coblong, padma, sampyan (nagasari, sesedep, penyeneng), lis padma, } \\
\text { bungkak, terakhir diisi canang. }\end{array}$ \\
\hline 2 & $\begin{array}{l}\text { Prayascita } \\
\text { Luwih }\end{array}$ & $\begin{array}{l}\text { Taledan sesayut mejaro atau bibih kulit sayut mesebeh (seperti tamas) } \\
\text { diletakkan diatas dulang, raka-raka selengkapnya, nasinya ( } 1 \text { buah tulung } \\
\text { urip ditengah-tengah yang berisi tumpeng) dibagian depan tulung urip } \\
\text { berjejer : } 11 \text { untek, } 11 \text { tulung ngeleb (tulung sesapi), } 11 \text { tetanceb, } 11 \text { buah } \\
\text { kwangen, } 11 \text { buah tipat pandawa rangkap atau tipak glatik diatur } \\
\text { sedemikian rupa sehingga tampak indah. Kojong rangkadan, pebresihan } \\
\text { payasan, tulung sayut, setangkir beras kuning, payuk prayascita, } 1 \text { buah } \\
\text { coblong, } 1 \text { buah kelapa gading dikasturi }\end{array}$ \\
\hline
\end{tabular}

2 Sumber : Ida Pedanda Istri Kania, Griya Abiansemal Denpasar, Wawancara tanggal 22 Maret 2006.

Tabel 3. Jenis Banten Prayascita ${ }^{3}$

\begin{tabular}{|c|c|c|}
\hline No & $\begin{array}{c}\text { Jenis } \\
\text { Prayacita }\end{array}$ & Tetandingan \\
\hline 1 & $\begin{array}{l}\text { Prayascita } \\
\text { Biasa }\end{array}$ & $\begin{array}{l}\text { Medasar antuk tetempeh, } 1 \text { buah niru yang kecil diatasnya diletakkan } \\
\text { kulit sesayut, raka woh-wohan, nasi bundar maklongkong, dibawah nasi } \\
\text { diisi daun tabia bun } 5 \text { lembar yang dijahit berbentuk bundar, diatas nasi } \\
\text { ditancapkan ujung daun dadap } 3 \text { lembar dan } 3 \text { lembar ujung padang } \\
\text { lepas, kojong rangkadan, peras, tulung, sayut, lis, padma, penyeneng } \\
\text { tehenan (penyeneng alit), canang payasan, sampyan nagasari, sesedep, } \\
\text { tepung tawar, kelapa gading, coblong payuk pere } 1 \text { buah. }\end{array}$ \\
\hline 2 & $\begin{array}{l}\text { Prayascita } \\
\text { Bumi }\end{array}$ & $\begin{array}{l}1 \text { kulit sayut, } 9 \text { tumpeng bewarna diletakkan sesuai pengideran, } 5 \text { ketipat } \\
\text { sari, } 5 \text { ketipat sidhapurna, } 5 \text { ketipat pandawa, } 5 \text { tulung urip, } 5 \text { tulung } \\
\text { sangkur, } 5 \text { penek, } 5 \text { bantal pudak, } 5 \text { pisang gading, } 1 \text { ekor bebek puth } \\
\text { diguling, } 1 \text { buah lis dari janur kelapa gading, } 1 \text { buah sibuh pepek selem } \\
\text { diisi tirta empul. }\end{array}$ \\
\hline 3 & $\begin{array}{l}\text { Prayascita } \\
\text { Kawi }\end{array}$ & $\begin{array}{l}\text { Medasar antuk dulang diatasnya dialasi sesayut, } 1 \text { tumpeng gede, } 2 \\
\text { tumpeng alit, tumpeng gede tancebin kwangen } 3 \text {, tetebus } 3 \text { pasang terbuat } \\
\text { benang putih, sudhamala dan tridatu, tumpeng yang kecil tancebin bunga } \\
\text { warna-warni, } 2 \text { buah tulung, jajan sarwa galahan, buah-buahan seadanya, } \\
1 \text { buah penyeneng alit, } 1 \text { pras alit, } 1 \text { sampyan nagasari, canang payasan. }\end{array}$ \\
\hline
\end{tabular}

3 Sumber : Mpu Jaya Wijayananda, tahun 2003

Tabel 4. Jenis Banten Prayascita ${ }^{4}$

\begin{tabular}{cll}
\hline No & $\begin{array}{c}\text { Jenis } \\
\text { Prayacita }\end{array}$ & \multicolumn{1}{c}{ Tetandingan } \\
\hline 1 & $\begin{array}{l}\text { Prayascita } \\
\text { Biasa }\end{array}$ & $\begin{array}{l}\text { Kulit sesayut, kulit peras berbentuk bundar, nasi, rerasmen, jajan, buah- } \\
\text { buahan, sorohan alit, pesucian, penyeneng, sampyan nagasari, babuu, } \\
\text { padma, lis senjata, kelapa gading muda (kelungah), air bersih dan tirta } \\
\text { yang dimohon dari sulinggih. }\end{array}$ \\
& $\begin{array}{l}\text { Prayascita } \\
\text { Sakti }\end{array}$ & $\begin{array}{l}\text { Kulit sesayut, kulit peras berbentuk bundar, nasi berbentuk bundar diisi } \\
\text { rerasmen 5 iris dan telor dadar diletakkan sesuai arah mata angin, } \\
\text { dibagian hulu diletakkan buah-buahan, jajan, sorohan alit (peras, tulung, } \\
\text { sayut), pesucian, penyeneng, sampyan naga sari, babuu, padma, lis } \\
\text { senjata, bungkak kelapa gading dikasturi. }\end{array}$ \\
& &
\end{tabular}

KULTURISTIK: Jurnal Bahasa dan Budaya E-ISSN: 2580-4456 P-ISSN: 2580-9334

Copyright $(\mathbf{C} 2017$ 
Vol. 1, No. 1, Juli 2017, 82

Available Online at https://ejournal.warmadewa.ac.id/index.php/kulturistik DOI: dx.doi.org/10.22225/kulturistik.1.1.219

Tabel 5. Jenis Banten Prayascita ${ }^{5}$

\begin{tabular}{|c|c|c|}
\hline No & $\begin{array}{c}\text { Jenis } \\
\text { Prayacita }\end{array}$ & Tetandingan \\
\hline 1 & $\begin{array}{l}\text { Prayascita } \\
\text { Biasa }\end{array}$ & $\begin{array}{l}\text { Alasnya tamas sayut/ taledan sesayut, raka-raka, nasinya berbentuk bundar } \\
\text { maklongkong, beralaskan tamas sesayut, } 5 \text { lembar daun tabia buun dijahit, } \\
\text { diatas nasi maklongkong ditancapkan } 3 \text { pucuk daun dadap, } 3 \text { pucuk } \\
\text { padang lepas, } 1 \text { kojong rangkap/ rangkadan berisi rerasmen, } 1 \text { soroh peras, } \\
\text { tulung, sayut diikat jadi satu, } 1 \text { pebresian payasan, } 1 \text { takir beras kuning, } 1 \\
\text { takir reranggitan, sampyan dan perlengkapan yang lain : sampyan } \\
\text { nagasari, } 1 \text { buah sesedep, penyeneng, wadah uyah, padma, lis padma, } 1 \\
\text { buah coblong, } 1 \text { buah payuk prayascita, canang, bungkak kelapa gading, } \\
\text { tirta yang dimohon dari sulinggih. }\end{array}$ \\
\hline 2 & $\begin{array}{l}\text { Prayascita } \\
\text { Sakti }\end{array}$ & $\begin{array}{l}\text { Tamas sesayut mejaro, ditengah-tengah diletakkan kulit peras bundar dari } \\
\text { lingkaran daun tabia bun } 8 \text { lembar. Isinya raka-raka selengkapnya seperti } \\
\text { apel, jeruk, salak, pisang, tebu, jajan, tape, bantal dan lain-lain. Nasinya } \\
\text { berbentuk bundar maklongkong, diatas nasi diisi } 5 \text { iris telor dadar sesuai } \\
\text { dengan pengider, kojong rangkadan berisi rerasmen, } 1 \text { soroh peras dan } \\
\text { tulung sayut, pebresian payasan, } 1 \text { tanding banten peras kecil, } 1 \text { takir beras } \\
\text { kuning, } 1 \text { takir reringgitan, } 1 \text { buah kelapa gading (bungkak) dikasturi, } \\
\text { sampian nagasari, sesedep, wadah uyah, padma, lis padma, coblong, payuk } \\
\text { prayascita, tirta dari sulinggih. Semua jejahitan terbuat dari janur kelapa } \\
\text { gading. }\end{array}$ \\
\hline 3 & $\begin{array}{l}\text { Prayascita } \\
\text { Luwih }\end{array}$ & $\begin{array}{l}\text { Alasnya tamas sesayut mejaro, raka-raka selengkapnya, nasinya : } 1 \text { buah } \\
\text { sampyan, tulung urip, tumpeng putih besar, } 1 \text { buah kojong rangkadan, } 1 \\
\text { soaroh peras tulung sayut, } 1 \text { tanding pebresian payasan, } 1 \text { takir beras } \\
\text { kuning, } 1 \text { tangkir reringgitan, } 1 \text { buah kelapa gading (bungkak) dikasturi, } 1 \\
\text { buah payuk prayascita, } 11 \text { buah tulung ngeleb berisi nasi dan kacang saur, } \\
11 \text { buah kwangen, } 11 \text { buah tipat gelatik, } 11 \text { buah penek, sampiannya }: 1 \\
\text { buah lis padma, } 11 \text { buah tetanceb, padma dan coblong,, nagasari, sesedep, } \\
\text { cerawis/ wadah uyah, canang sari, tirta dari sulinggih. }\end{array}$ \\
\hline
\end{tabular}

Tabel 6. Jenis Banten Prayascita ${ }^{6}$

\begin{tabular}{|c|c|c|}
\hline No & $\begin{array}{c}\text { Jenis } \\
\text { Prayacita }\end{array}$ & Tetandingan \\
\hline 1 & Prayascita & $\begin{array}{l}\text { Alas kulit sesayut : } 1 \text { buah kulit peras bundar, } 1 \text { buah nasi berbentuk } \\
\text { bundar, diatasnya diletakkan } 5 \text { iris telor dadar sesuai mata angin, raka-raka } \\
\text { (woh-wohan, jajan, pisang, tebu, dan lain-lain), rerasmen (kacang, saur, } \\
\text { gerang, dan lain-lain), } 1 \text { buah sampyan nagasari/ sampian kembang, } \\
\text { alasnya memakai kulit sesayut, diatasnya diletakkan tulung besar berisi } \\
\text { penek masiwer (dilingkari plekir atau trikona, diatasnya disusun cerawis/ } \\
\text { wadah uyah disekelilingnya diletakkan } 5 \text { buah tulung kecil lengkap berisi } \\
\text { rerasmen, raka-raka, kwangen } 5 \text { buah, diatasnya diletakkan sampyan } \\
\text { nagasari. }\end{array}$ \\
\hline 2 & $\begin{array}{l}\text { Prayascita } \\
\text { Sakti }\end{array}$ & $\begin{array}{l}\text { Alasnya sebuah kulit sesayut, ditempeli } 2 \text { buah tangkih yang masing- } \\
\text { masing diisi jajan dan buah-buahan, diatasnya kulit peras bundar (maiseh) } \\
\text { disusun nasi bentuknya bundar, diatas nasi diletakkan } 5 \text { atau } 8 \text { iris telor } \\
\text { dadar sesuai arah mata angin, bawang putih } 8 \text { siung, masing-masing } \\
\text { dialasi jejahitan kukun kambing, disekitarnya dilengkapi rerasmen, raka- } \\
\text { raka dan paling atas diletakkan sebuah sampyan kembang/ nagasari. } \\
\text { Perlengkapan lain terdiri dari : penyeneng, pebresihan, lis bebuu, padma, } \\
\text { lis senjata, canang genten, kelapa gading (bungkak) dikasturi, toya anyar } \\
\text { dan tirta dari sulinggih. }\end{array}$ \\
\hline
\end{tabular}

berlanjut

KULTURISTIK: Jurnal Bahasa dan Budaya E-ISSN: 2580-4456 P-ISSN: 2580-9334 
Vol. 1, No. 1, Juli 2017, 83

Available Online at https://ejournal.warmadewa.ac.id/index.php/kulturistik DOI: dx.doi.org/10.22225/kulturistik.1.1.219

lanjutan

\begin{tabular}{|c|c|c|}
\hline No & $\begin{array}{c}\text { Jenis } \\
\text { Prayacita }\end{array}$ & Tetandingan \\
\hline 3 & $\begin{array}{l}\text { Prayascita } \\
\text { Luwih }\end{array}$ & $\begin{array}{l}\text { Alasnya memakai sebuah kulit sesayut, diatasnya diisi beras, base tampel, } \\
\text { uang dan benang, diatasnya disusun kulit peras } 11 \text { buah, daun tabia bun } 11 \\
\text { lembar, penek memakai siwer atau plekir } 11 \text { buah, tulung mata } 11 \text { buah, } \\
\text { kwangen } 11 \text { buah. Sebuah tulung besar didalamnya berisi mesiwer, wadah } \\
\text { uyah, raka-raka, paling atas diletakkan sampyan kembang/ nagasari. } \\
\text { Perlengkapan terdiri dari sorohan alit (peras, tulung, sesayut), penyeneng, } \\
\text { lis senjata, sebuah payuk pere berisi toya anyar, kelapa gading (bungkak) } \\
\text { dikasturi, tirta dari sulinggih. Alasnya memakai sebuah kulit sesayut, } \\
\text { disusun kulit peras, } 5 \text { sesayut, } 5 \text { buah penek lancip, tulung mata } 5 \text { buah, } \\
\text { ketipat tebasan } 5 \text { buah, kwangen } 5 \text { buah ditancapkan, congger } 5 \text { buah } \\
\text { ditancapkan, } 1 \text { buah tulung urip berisi cerawis/ wadah uyah, diatasnya } \\
\text { diletakkan sampian pusung. }\end{array}$ \\
\hline 4 & $\begin{array}{l}\text { Prayascita } \\
\text { Kawi }\end{array}$ & $\begin{array}{l}\text { Alasnya memakai sebuah kulit sesayut, diatasnya berisi kulit peras } \\
\text { bundar, diatas kulit peras diletakkan } 5 \text { lembar daun tabia bun/ daun } \\
\text { lombok dijahit jadi satu menunjuk mata angin, diatasnya diletakkan nasi } \\
\text { yang bentuknya bundar disusun wadah uyah/ cerawis ditancapi ujung } \\
\text { cabang dadap } 3 \text { batang, dilengkapi sebelahnya beras kuningmemakai alas } \\
\text { takir, raka-raka, rerasmen beralaskan kojong krangkadan, bawang puth } \\
\text { beralaskan kukun kambing, diatasnya memakai sampian kembang/ } \\
\text { nagasari. Perlengkapan lainnya terdiri dari : sorohan alit (peras, tulung, } \\
\text { sesayut), pebersihan, penyeneng, lis bebuu, padma, lis senjata, kelapa } \\
\text { gading (bungkak) dikasturi, toya anyar dan tirta dari sulinggih. }\end{array}$ \\
\hline
\end{tabular}

${ }^{6}$ Sumber : Dra. Ni Made Sri Arwati, “ Byakala Tebasan Durmanggala dan Prayascita”, 2003

Tabel 7. Jenis Banten Prayascita ${ }^{7}$

\begin{tabular}{|c|c|c|}
\hline No & $\begin{array}{c}\text { Jenis } \\
\text { Prayacita }\end{array}$ & Tetandingan \\
\hline 1 & $\begin{array}{l}\text { Prayascita } \\
\text { Biasa }\end{array}$ & $\begin{array}{l}1 \text { buah kulit sayut, } 5 \text { lembar daun tabia bun dijahit bundar dan ditempel } \\
\text { pada kulit sayut, raka-raka, pisang, tebu, jajan, begina merah putih, bantal } \\
\text { dan tape, } 1 \text { buah nasi maklongkong, } 1 \text { buah kojong rangkap isi rerasmen } \\
\text { lengkap, } 1 \text { buah sorohan alit, payasan pebresian, penyeneng an tetebus, } \\
\text { sampian nagasari, lis senjata, padma dan sesedep, kelapa gading } \\
\text { (bungkak), } 3 \text { muncuk padang lepas, } 3 \text { muncuk ambengan/ alang-alang, } 3 \\
\text { lembar daun dadap, toya bersih dan tirta dari sulinggih. Padang lepas, } \\
\text { alang-alang dibungkus daun dadap, diikat benang tridatu (warna merah, } \\
\text { hitam, putih) ditancapkan pada nasi maklongkong. }\end{array}$ \\
\hline 2 & $\begin{array}{l}\text { Prayascita } \\
\text { Luwih }\end{array}$ & $\begin{array}{l}1 \text { buah dulang, diatas dulang diisi kulit sayut bentuknya bundar mejaro. } \\
\text { Diatas kulit sayut diisi tamas mejaro atau kulit sayut, } 8 \text { lembar daun tabia } \\
\text { bun dijahit pada kulit sayut, raka-raka (pisang, tebu, apel, jajan, tape, } \\
\text { bantal dan lain-lain), ditengah-tengah diisi tulung urip yang berisi satu } \\
\text { buah tumpeng putih besar, } 1 \text { buah kojong rangkadan isinya rerasmen, } 1 \\
\text { soroh peras, tulung, sayut, } 1 \text { tanding payasan pebresihan, } 1 \text { takir beras } \\
\text { kuning, } 1 \text { takir reringgitan terdiri suah, sisir dan cermin. } 1 \text { buah kelapa } \\
\text { gading (bungkak) dikasturi, } 1 \text { buah payuk prayascita, } 11 \text { buah tulung } \\
\text { sesapi ngeleb dan kacang saur, } 11 \text { buah kwangen, } 11 \text { buah tipat gelatik, } 11 \\
\text { buah untek atau penek, } 1 \text { sampian nagasari, } 1 \text { buah lis, padma, } 11 \text { buah } \\
\text { tetanceb, } 1 \text { buah sesedep, } 1 \text { buah wadah uyah, } 1 \text { buah payuk prayascita, } \\
\text { canang sari, tirta dari sulinggih. }\end{array}$ \\
\hline
\end{tabular}

7 Sumber : Ida Ayu Mirah (Tukang Banten), Griya Tegeh Banjar Lebah Denpasar. Wawancara tanggal 6 Juni 2006. 
Vol. 1, No. 1, Juli 2017, 84

Available Online at https://ejournal.warmadewa.ac.id/index.php/kulturistik DOI: dx.doi.org/10.22225/kulturistik.1.1.219

Tabel 8. Jenis Banten Prayascita ${ }^{8}$

\begin{tabular}{|c|c|c|}
\hline No & $\begin{array}{c}\text { Jenis } \\
\text { Prayacita }\end{array}$ & Tetandingan \\
\hline 1 & $\begin{array}{l}\text { Sesayut } \\
\text { Prayascita }\end{array}$ & $\begin{array}{l}\text { Kulit sesayut, raka-raka, } 1 \text { buah sampian nagasari, sesedep, } 1 \text { buah } \\
\text { jejahitan seroja (seperti sampian nagasari), } 1 \text { buah padma, } 5 \text { buah } \\
\text { tumpeng memakai pekir metanceb kwangen, } 1 \text { buah limas berisi sambal } \\
\text { dan garam, } 5 \text { buah tipat gelatik, } 5 \text { buah tulung sangkur, } 1 \text { buah lis senjata, } \\
1 \text { buah penyeneng, } 1 \text { buah bungkak kelapa gading, } 1 \text { buah limas berisi } \\
\text { saur kacang, gerang, timun, tuwung, } 1 \text { buah nasi soda meklongkong. }\end{array}$ \\
\hline 2 & $\begin{array}{l}\text { Prayascita } \\
\text { Luwih }\end{array}$ & $\begin{array}{l}\text { Kulit sesayut, raka-raka, } 10 \text { buah tumpeng memakai pekir ditancapkan } \\
\text { sebuah kwangen dengan posisi pengideran, } 10 \text { buah tulung urip letaknya } \\
\text { berdampingan dengan tumpengnya, } 10 \text { buah tipat gelatik letaknya disela- } \\
\text { sela antara tumpeng dan tulung urip, } 1 \text { buah penyeneng, } 1 \text { buah nasi soda } \\
\text { ageng meklongkong mepekir pada penampang atas dan bawah, } 1 \text { buah } \\
\text { cili, } 1 \text { buah lis gede, } 1 \text { buah padma, } 1 \text { buah sroja dari daun tabia bun, } \\
\text { padang lepas } 11 \text { batang, } 1 \text { buah sampian nagasari, } 1 \text { buah takir berisi } \\
\text { beras kuning dicampur daun temen, kemoning dan daun dadap, } 1 \text { buah } \\
\text { bungkak kelapa gading. }\end{array}$ \\
\hline
\end{tabular}

8 Sumber : sumber I B Putu Sudarsana “ Himpunan tetandingan Upakara Yadnya” Edisi III Revisi

Menurut I B Sudharsana jenis banten prayascita ada 2 macam yaitu banten sesayut prayascita dan banten prayascita luwih.

Dalam penelitian ini ditampilkan bentuk banten prayascita yang umum digunakan dalam pelaksanaan upakara Agama Hindu di Pura Kampus UNHI Denpasar.

1. Bentuk banten sesayut prayascita (Pelatihan membuat banten piodalan alit dan otonan di Kampus UNHI Denpasar, tanggal 31 Juni 2006) dengan nara sumber Drs. I. B. Putu Sudarsana, MBA., MM. Dan Dra. Ni Wayan Wandri, MSI. Komponen banten sesayut prayascita, sebagai berikut :

a) Kulit sayut,

b) Nasi berbentuk bundar maklongkong, beralaskan kulit sesayut yang sudah dijahitkan lima atau delapan lembar daun tabia bun,

c) Raka-raka (pisang, jeruk, manggis, tebu, dan lain-lain)

d) Kojong rangkap berisi rerasmen (kacang saur, gerang, timun, dan lainlain)

e) 5 buah Tipat gelatik/ kukur 5 buah

f) 5 buah Tumpeng berisi plekir bungan duren

g) 5 buah tulung berisi nasi, kacang dan saur

h) 5 buah kwangen

i) Pabersihan payasan

j) 1 takir beras kuning

k) 1 takir reringgitan

1) 1 buah bungkak kelapa gading dikasturi

m) Sampian :

- Nagasari

- Penyeneng

- Sesedep

- Tempat garam (wadah uyah)

- Padma

- Lis Senjata 

n) Coblong
o) Payuk prayascita dilengkapi tirta dari sulinggih
p) Canang Sari

2. Bentuk banten prayascita sakti sebagian besar komponennya sama dengan prayascita biasa. Perbedaan antara prayscita biasa dengan prayascita sakti hanya pada beberapa komponen, diantaranya
a) Tamas mejaro/ kulit sayut diatasnya dijahitkan kulit pers bundar
b) Nasi berbentuk bundar, diatasnya diisi 5 atau 8 iris telor dadar sesuai dengan arah mata angin
c) 1 soroh banten peras, tulung dan sayut (sorohan alit)
d) Semua jejahitan menggunakan janur kelapa gading

\section{SIMPULAN}

Prayascita memiliki bentuk dan jenis yang beraneka ragam, berbeda-beda antara yang satu dengan yang lainnya sesuai dengan sumber dari prayascita tersebut. Banten prayascita merupakan sarana penting dalam mewujudkan kesucian pelaksanaan upacara yadnya, didominasi oleh unsur-unsur Dewa Siwa. Hal ini dapat dimengerti mengingat Dewa Siwa sebagai pelebur semua keletehan dan mala guna mewujudkan kesucian upacara. Banten Prayascita selalu digunakan dalam upacara panca yadnya baik pada tingkatan nista, madya, maupun uatama mandala. Dalam pembuatan banten prayascita ditemukan pendidikan seni dan budaya dengan menciptakan jejahitan dan reringgitan yang indah, melukiskan simbol-simbol dewa yang mencermikan nilai keindahan yang sangat tinggi.

\section{DAFTAR PUSTAKA}

Anom, I. A. N. (1987). Arti dan fungsi kayu dadap dalam kehidupan masyarakat hindu di Bali. Denpasar: Universitas Hindu Indonesia.

Arwati, N. M. S. (1993). Jenis jenis banten sesayut. Denpasar: Upada Sastra.

Putra, I. G. A. M. (2000). Upacara Dewa Yadnya. Denpasar.

Rana, T. M. (1972). Tjara membuat lis di Pajangan (Gianjar). Denpasar: Universitas Udayana.

Rasni, N. W. (1983). Fungsi upacara sesayut prayascita gumi dalam upacara Budha yadnya di kabupaten Badung. Denpasar: Universitas Hindu Indonesia.

Rianingsih, P. (2004). Faktor-faktor yang berpengaruh terhadap pengembangan usaha Canang Sari di Kabupaten Badung. Denpasar: Universitas Hindu Indonesia.

Sudarsana, I. B. P. (2002). Ajaran agama Hindu (filsafat yadnya). Denpasar: Mandara Sastra.

Sudarsana, I. B. P., \& Dkk. (n.d.). Himpunan tetandingan upakara yadnya. Denpasar: Yayasan Dharmaacarya.

Suika, I. W. (1981). Arti dan fungsi lis dalam upacara piodalan di Pura Jaganatha. Denpasar: Universitas Hindu Indonesia.

Titib, I. M. (2003). Teologi simbol - simbol dalam agama Hindu. Surabaya: Paramitha.

Wijayananda, M. J. (2004). Tetandingan lan sorohan banten. Surabaya: Paramitha. 